\title{
Historicising Accountability: Berlin’s Energy Transitions
}

Timothy Moss

\begin{abstract}
This chapter explores accountability and energy transitions through the lens of historical analysis. It reinterprets empirical research on the history of Berlin's energy systems to illustrate how accountability and legitimacy are political constructs of a particular time and place. Three periods of reconfiguration to urban electricity and gas networks, chosen from across Berlin's turbulent past century, illustrate this diversity. The chapter outlines each selected case and its pertinence to energy accountability. It then describes what crisis of accountability was prevalent in each instance and its treatment in the literature. The practices of legitimation enrolled to justify energy strategies are subsequently highlighted, as are forms of resistance and attempts to delegitimise the dominant discourse. The conclusion summarises the implications of historicising accountability for energy transitions research.
\end{abstract}

Keywords Accountability $\bullet$ Legitimacy $\bullet$ Berlin $\bullet$ Energy $\bullet$ History

T. Moss $(\bowtie)$

Integrative Research Institute on Transformations of Human-Environment Systems (IRI THESys), Humboldt University of Berlin, Berlin, Germany e-mail: timothy.moss@hu-berlin.de

(C) The Author(s) 2020

S. Sareen (ed.), Enabling Sustainable Energy Transitions, https://doi.org/10.1007/978-3-030-26891-6_4 


\subsection{What Is the Case and Why Is It an Energy Transitions Case?}

This chapter explores ways of contextualising accountability and accountability crises, both temporally and spatially. Using the case of Berlin over the past 100 years, it aspires to enrich debate on accountability in energy transitions - the focus of this book-by reflecting on historical precedents that can challenge some 'presentist' assumptions underpinning much of this work. Following the editor's invitation (Sareen 2019), I reframe ongoing and published research on Berlin's multiple energy transitions (Moss 2014, 2016; Becker et al. 2017) in terms of crises of accountability and practices of legitimation. In doing so, I hope to sensitise future research on this topic to the importance of time and space. The underlying question guiding the chapter is: how can historicising accountability contribute to our understanding of energy transitions and ways of researching them?

Berlin lends itself to such an analysis in part because accountability has, today, become a key issue of contention over the future of the city's energy infrastructures (Becker et al. 2015, 2017; Blanchet 2015). Over the past decade, criticism of the city's electricity and gas utilities, which were both fully privatised during the 1990s, has targeted not only their reluctance to embrace the low carbon agenda but also-significantly-their resistance to public scrutiny and the democratisation of decision-making processes. A local referendum to remunicipalise Berlin's electricity grid narrowly failed in November 2013, but the campaign generated two social movements. These have since managed to reframe energy policy debates in the city around issues of accountability, participation and transparency. The first is the Berlin Energy Roundtable (Berliner Energietisch), a coalition of approximately 50 environmental, leftist and anti-gentrification organisations that calls for a democratic, ecologically oriented and socially just 'citizens' utility'. The second is an energy cooperative, Citizen Energy Berlin (BürgerEnergie Berlin), that is at least partly owned by a collective of consumers. Pressure from both organisations has succeeded in changing the city government's policy, which in its current red-red-green complexion has established a small publicly owned energy utility in direct competition with the incumbent Vattenfall. This utility-Berlin Energie-is designed to be more accountable not only to local politicians but also to local energy consumers.

While restricting attention to this ongoing experiment in urban energy democracy would be revealing enough about how accountability is being 
framed and institutionalised today, it would say nothing about the historical context of energy accountability in the city. What makes Berlin interesting in this context are the different kinds of energy transition it has witnessed during its turbulent recent history. In the course of the past 100 years, Berlin has experienced political regimes of unparalleled range-from democratic to fascist to state-socialist- that each tried to mould urban energy policy in their own image. It is these multiple energy transitions, rather than the one, low carbon energy transition of today, which are the empirical focus of this chapter. The task is to compare the current with earlier phases of energy transition (in senso lato) in order to reveal how accountability has been variously invoked and what practices of legitimation have been enrolled to justify action.

The challenges of this venture are considerable. Apart from investigating energy transitions very different to the one pursued today, the societal norms framing both form and content of legitimacy (cf. Bäckstrand et al. 2018) underwent massive shifts during the course of the twentieth century. Accountability under National Socialism was not about the government serving the people, but the people serving Führer and Volk. In East Germany, the Socialist Unity Party established itself as the steward of the working class to which all citizens should pay obeisance. These extreme examples illustrate how much accountability and legitimacy are political constructs of their time, and indeed, of specific places. Although focusing on such undemocratic regimes could be instructive, this chapter instead selects examples of urban energy transitions drawn from Berlin's more democratically constituted governance systems, in order to generate findings of greater relevance to most contexts today. Three periods of transition have been chosen: (1) creating model municipal energy utilities for the new Greater Berlin in the 1920s, (2) sustaining energy autarky in an isolated West Berlin during the Cold War and (3) democratising urban energy governance in the city today. As argued later, they constitute cases of the politics of distribution, protection and representation, respectively.

\subsection{What Crises of Accountability Are Being Maintained or Challenged?}

The crisis of accountability in 1920s Berlin revolved around who should be responsible for supplying the burgeoning metropolitan area with public services, including electricity and gas. Prior to 1920, Berlin was geograph- 
ically minute, surrounded by powerful bourgeois-led municipalities that had successfully resisted amalgamation, thanks to the restrictive suffrage in Prussia. The large cities around Berlin each had their own energy utilities, which they zealously protected. The German revolution of 1918-1919 and the introduction of universal suffrage opened the floodgates for socialist schemes that were geared to substantiate the promise of democracy with more equitable and affordable public services for all. The creation of Greater Berlin in 1920 marked a milestone of this kind. Amalgamating seven cities, 59 smaller municipalities and 27 landed estates, the new Berlin grew 12 -fold in size. It incorporated all existing municipal energy companies into its own electricity and gas utilities (Bewag and Gasag), which were, henceforth, entrusted with implementing territorial unification by means of uniform service standards, tariffs and working conditions. To the new government of Greater Berlin, it was of critical importance to have a single utility accountable to a single city authority in the provision of power or gas services. Equally important was the provision of electricity and gas produced by the city's own utilities. This involved resisting persistent approaches by the major national energy providers of the day, Reichselektrowerke A.G. and Ruhrgas A.G., to supply the capital as part of their own programmes of territorial expansion and system centralisation (Fig. 4.1).

In West Berlin of the 1970s, a very different crisis of accountability emerged around the city's energy provision. Ever since the Berlin blockade of 1948/1949 and the subsequent political division of the city, West Berlin had sought to minimise dependence on East Germany and East Berlin by generating its own electricity and producing its own (town) gas. This strategy of urban energy autarky required a huge number of power and gas plants to be built within the city limits, but this was toleratedindeed, celebrated-by West Berlin residents throughout the 1950s and 1960s as a symbol of defiance of the 'insular city'. Decisions by the city's power utility to build ever more generating capacity were not questioned for fear of appearing to undermine West Berlin's very existence. By the 1970s, however, popular resistance to the serious environmental and public health hazards posed by continuous infrastructure expansionespecially to the city's air quality and ecosystems - was posing a massive threat to the compact of non-accountability between utility and citizen. The more the energy utilities insisted on the need for additional plants to keep West Berlin functioning, the more the protestors questioned the fun- 


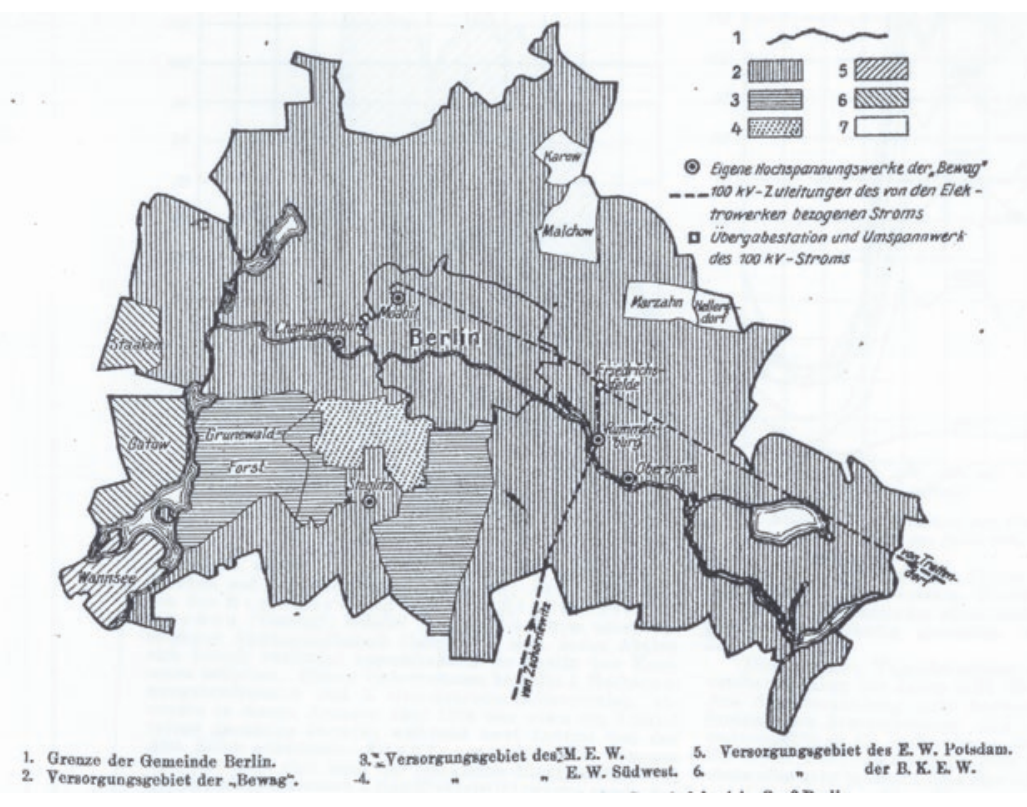

Fig. 4.1 Map showing size of Berlin prior to 1920 (marked core area) and territory of municipalised power utilities by 1925 (vertically striped area). (Source: Bruno Thierbach, 1925, Die gegenwärtige Versorgung der Stadt Berlin und der Provinz Brandenburg mit elektrischer Arbeit. Elektrotechnische Zeitschrift, 46(39), 1465)

damental assumptions on which the call for increased capacity was based. The issue came to a head in 1976-1977 over a decision by the city government and its power utility to build a new 600-Mega Watt power plant in the middle of one of the city's remaining forests. Massive protests and prolonged court cases resulted in the planned power plant being stopped, but not before it had been revealed to the public how both Bewag and the city government were prepared to ride roughshod over legal constraints and societal norms in order to achieve their common goal. Bewag's public image never really recovered from the damage this affront to public accountability caused amongst the population (Mielke and Weiß 1977). The case of the rejected power plant became a milestone of energy governance in Germany (Fig. 4.2). 


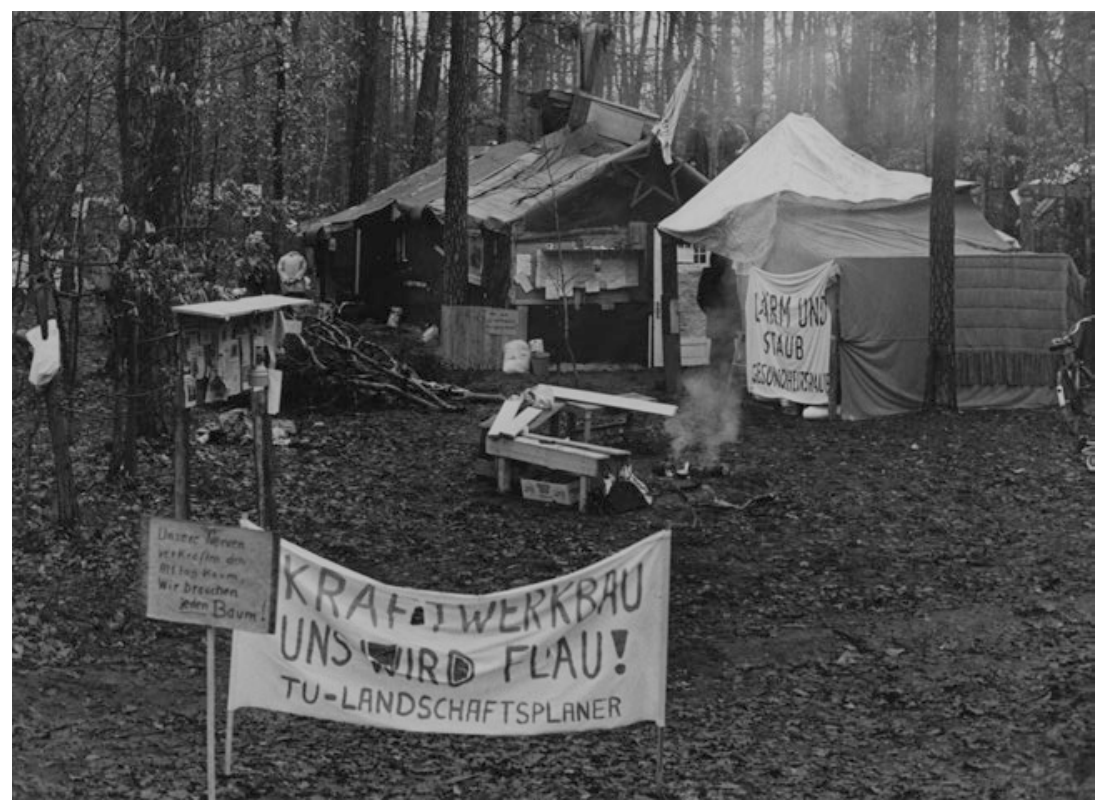

Fig. 4.2 Protest camp against the planned power plant in Spandau Forest, 1976. (Source: Landesarchiv Berlin, F Rep 290, No. 0194-662)

Today's accountability crisis revolves around the ownership and control of the city's energy systems. The renewal of the concession agreements for the electricity grid and gas network in 2014 provided a window of opportunity for the two grassroots initiatives-the Berlin Energy Roundtable and Citizen Energy Berlin-to challenge the position of the incumbent utilities: Vattenfall and Gasag. Whilst the Roundtable has campaigned for the city to take over the electricity concession in one form or another, the cooperative has sought to take it on itself in partnership with others. A very public contestation has emerged between Vattenfall and its opponents over the future of Berlin's power grid. Vattenfall has argued that only it possesses the experience and expertise necessary to run a complex electricity system. The civil society organisations have countered that only an accountable municipal utility can deliver on policy targets for renewable energy and decarbonisation. The dispute landed in the courts and was only resolved - in favour of the new municipal utility Berlin Energie-in March 2019 (Fig. 4.3). 
Fig. 4.3 Campaign poster of the Berlin Energy Roundtable for the 2013 referendum, reading 'Our municipal utility, our power grid, our Berlin'. (Source: http://www.berlinerenergietisch.net/ materialien)

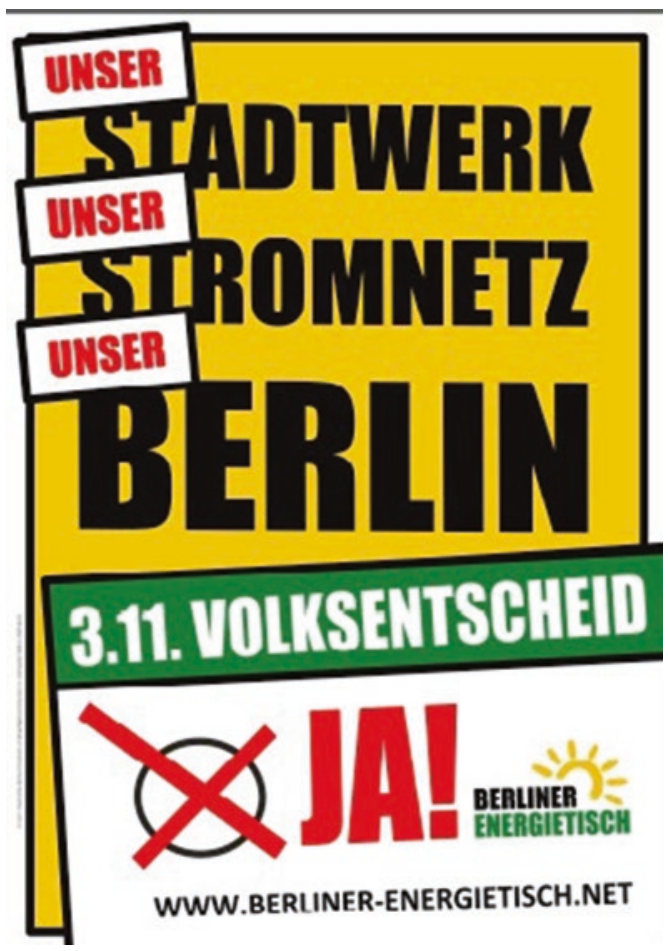

\subsection{How Do Environmental Governance Scholars Characterise the Case?}

The story of Berlin's energy policy in the 1920s has been told only by the author, and to date only from selective perspectives. These perspectives have highlighted interest in balancing electricity load curves with demand management measures (Moss 2014) and the rise and fall of alternative energy technologies in the interwar years (Moss 2016).

The impact of political division on West Berlin's energy infrastructures and utilities was analysed initially by the political scientist Richard Merritt in the 1960s, but not with respect to environmental issues (Merritt 1968). The author of this chapter has explored how division nurtured a strategy of spatial reorientation and self-dependence of energy provision around the insular city (Moss 2009) that largely failed to entertain options for saving energy or using it more efficiently (Moss 2014). 
By contrast, in Berlin today, there is considerable academic interest in initiatives to reform energy governance and reconfigure energy infrastructures (Becker et al. 2015, 2017; Blanchet 2015). What captivates these environmental governance scholars is the novel kind of collective control and accountability being advanced by the two social movements. Remunicipalisation, to these initiatives, means much more than returning a privatised utility to municipal ownership. It is about creating a wholly new kind of utility that is transparent to public scrutiny, open to joint decision-making by consumers and obliged by protocol to serve the public interest in keeping energy affordable and protecting the climate. This agenda is, as recent research reveals (Becker et al. 2015), broadening the scope of debate on energy governance in the city and undermining the previously unchallenged hegemony of the incumbent providers, notably Vattenfall.

\subsection{What Practices of Legitimation Appear to Be at Play in Empirical Work?}

In the 1920s, the core issue of legitimacy was creating uniform and affordable public services for the enlarged municipal entity of Greater Berlin. This had been the principal rationale for expanding the city's boundaries; after 1920, it needed to be put into practice. Municipal politicians never tired of emphasising the importance of the city's own energy (and water) utilities as instruments to this end. Practices enrolled to deliver the promise came in three forms: first, unitary tariffs across the territories of the newly united utilities (if not the whole city); second, uniform service standards for access, supply and maintenance; and third, fair and equal wages for employees across the city. These improvements to public services provided the justification for massive investments in urban infrastructure. The argument of uniform and fair services for Greater Berlin was mobilised repeatedly to rally local support for building state-of-the-art power stations (e.g., the Klingenberg plant) and experimenting with innovative technologies (e.g., heat storage for rapid power generation). The revenues generated from growing electricity sales, in particular, were used not only to fund these capital investments but also to support the beleaguered city budget, especially during the hyperinflation of 1922-1923 and depression during 1929-1933. The legitimacy of this policy of welfare expansionism did not go unchallenged. During the 1920s, the local Communist Party (KPD) criticised rising tariffs for hitting the poor hardest. Far more serious 
was the campaign launched by the Reichsbank President Hjalmar Schacht against the foreign loans used to fund much of Berlin's new energy infrastructure. By 1931, this culminated in the forced sale of most of the city's shares in Bewag to national and international energy conglomerates as a stop-gap measure to reduce the city's burgeoning debt.

In West Berlin during the Cold War, security was the overriding argument used to legitimise urban energy policy. Successive city governments and utility directors proclaimed, when any network expansion was planned, that failing to act would jeopardise the local economy and undermine West Berlin's capacity to provide its own electricity and gas. With the backing of the three Western Allied powers, high security standards were built into West Berlin's energy systems. These were epitomised by two core practices: first, storing sufficient reserves of primary energy (coal and oil) to power the city for at least three months and, second, creating a cascade of generating capacity capable of avoiding power outages even in the event that the largest generating block failed. The massive capital investments required for this security-oriented strategy did not need legitimising locally as they were heavily subsidised by the West German government. It was only in the 1970s, when fresh expansionist plans confronted an emergent environmentalist movement, that these practices of legitimation for West Berlin as an 'electricity island' were challenged seriously. For the first time, alternative models for energy provision in West Berlin were advanced by academics, activists and consultants. These revolved around reducing the need for new generating plant by promoting energy saving, using energy more efficiently (e.g., with small-scale co-generation), and, latterly, importing electricity from East German power plants upgraded with West German technology. These measures were deliberately framed to delegitimise the dominant narrative of build-and-supply.

The current conflict over Berlin's energy future is characterised by competing claims to legitimacy. On the one hand, the incumbent energy utilities (primarily Vattenfall, but also Gasag) present themselves to the public as the experts who, by virtue of their long-standing experience in running Berlin's energy systems, are the sole actors capable of managing the power grid and gas network. Technical expertise, track record and financial viability are the arguments they mobilise to justify their claims and belittle their competitors. On the other hand, the social movements campaigning for their kind of accountable remunicipalisation argue that it is precisely this reliance on traditional management criteria that is blocking attempts in the city to reduce energy use, cut carbon emissions and promote renew- 
able sources of energy. They are advancing a very different logic of legitimacy which targets global sustainability and local accountability. Significantly, they have managed to induce a shift in city government policy, from supporting the incumbent utilities to embracing a new municipal utility and a strategy of decarbonising the city's energy systems.

\subsection{What Interventions Could Enable Sustainable Outcomes Under Transition?}

Assessing historical examples in terms of sustainability norms is highly problematic, since sustainability—as currently understood-was not then an issue. Past interventions to reconfigure urban energy systems were made in the name of other overarching principles prevalent at the time, such as social equality or political security. What this brief foray into the past has revealed is, first, that crises of accountability over energy are not new. They have accompanied the emergence, consolidation and adaptation of energy systems since their early beginnings. Second, we have illustrated that what accountability can mean, how it is invoked, to what ends and through what mechanisms varies hugely according to particular contexts of time and space. What passes without arousing public disapproval in one context can be highly controversial in another. This prompts us to pause and reflect, when recommending practices of legitimation or modes of accountability governance, on what temporality might mean for their shelf-life and future-proofing. Today's accountability fix should not become tomorrow's accountability trap (Kramarz and Park 2017). Finally, the examples drawn from Berlin's history have shown how processes of legitimising energy transitions are inextricably bound up in much wider societal concerns, such as-in our three cases-the politics of distribution, protection and representation. Efforts to institutionalise sustainable energy transitions would, it follows, be well advised to heed, enrol or resist concurrent movements that are likely to influence-one way or another-the viability of a particular preferred pathway (Bouzarovski and Haarstad 2018).

\section{REFERENCES}

Bäckstrand, K., Zelli, F., \& Schleifer, P. (2018). The legitimacy and accountability in polycentric climate governance. In A. Jordan, D. Huitema, H. van Asselt, \& K. J. Forster (Eds.), Governing climate change: Polycentricity in action (pp. 338356). Cambridge: Cambridge University Press. 
Becker, S., Beveridge, R., \& Naumann, M. (2015). Reconfiguring energy provision in Berlin. Commoning between compromise and contestation. In M. Dellenbaugh, M. Kip, M. Bieniok, A. K. Müller, \& M. Schwegmann (Eds.), Urban commons. Moving beyond state and market (pp. 196-213). Basel: Birkhäuser.

Becker, S., Naumann, M., \& Moss, T. (2017). Between coproduction and commons: Understanding initiatives to reclaim urban energy provision in Berlin and Hamburg. Urban Research and Practice, 10(1), 63-85.

Blanchet, T. (2015). Struggle over energy transition in Berlin: How do grassroots initiatives affect local energy policy-making? Energy Policy, 78, 246-254.

Bouzarovski, S., \& Haarstad, H. (2018). Rescaling low-carbon transformations: Towards a relational ontology. Transactions of the Institute of British Geographers. https://doi.org/10.1111/tran.12275

Kramarz, T., \& Park, S. (2017). Introduction: The politics of environmental accountability. Review of Policy Research, 34(1), 1-4.

Merritt, R. L. (1968). Political division and municipal services in postwar Berlin. In J. D. Montgomery \& A. O. Hirschman (Eds.), Public policy (pp. 165-198). Cambridge, MA: Harvard University Press.

Mielke, H.-J., \& Weiß, H. (1977). Kraftwerksbau im Landschaftsschutzgebiet Spandauer Forst. Berliner Naturschutzblätter, 21(60/61), 251-255, 286-288.

Moss, T. (2009). Divided city, divided infrastructures: Securing energy and water services in postwar Berlin. Journal of Urban History, 35(7), 923-942.

Moss, T. (2014). Socio-technical change and the politics of urban infrastructure: Managing energy in Berlin between dictatorship and democracy. Urban Studies, $51(7), 1432-1448$.

Moss, T. (2016). Discarded surrogates, modified traditions, welcome complements: The chequered careers of alternative technologies in Berlin's infrastructure systems. Social Studies of Science, 46(4), 559-582.

Sareen, S. (2019). Five easy pieces: Legitimation at work in cases related to energy transitions. In Enabling sustainable energy transitions: Practices of legitimation and accountable governance. London: Palgrave Macmillan. 
Open Access This chapter is licensed under the terms of the Creative Commons Attribution 4.0 International License (http://creativecommons.org/licenses/ by $/ 4.0 /$ ), which permits use, sharing, adaptation, distribution and reproduction in any medium or format, as long as you give appropriate credit to the original author(s) and the source, provide a link to the Creative Commons licence and indicate if changes were made.

The images or other third party material in this chapter are included in the chapter's Creative Commons licence, unless indicated otherwise in a credit line to the material. If material is not included in the chapter's Creative Commons licence and your intended use is not permitted by statutory regulation or exceeds the permitted use, you will need to obtain permission directly from the copyright holder.

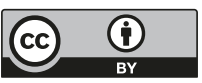

